stated in your September editorial? And if it be admitted, therefore, that deficient alkalinity causes acidosis, and acidosis is dissipated by protein diet, and pellagra is also dissipated by protein diet, may we not with reason propose that pellagra is a condition of deficient alkalinity or lowered alkaline equilibrium between bases and acids? George D. Fairbanks, M.D., Brownsville, Texas.

\section{Studies of Pellagra: a Correction}

To the Editor:-I have just read the editorial on "Studies of Pellagra" (The Journal, Nov, 20, 1915, p. 1818). In the second paragraph of the first column $I$ find the following: "As a result of epidemiologic studies, Goldberger had concluded in effect that pellagra is not a communicable disease, that it is dependent on some as yet undetermined fault in a diet in which the animal or leguminous vegetable component is disproportionately large," etc. This last word "large" is evidently a slip through inadvertence. It should be "small," so that the last part of the foregoing quotation should read, "that it is dependent on some as yet undetermined fault in a diet in which the animal or leguminous vegetable component is disproportionately small," etc.

JoSEPH GoLdBerger, M.D., Washington, D. C.

Surgeon in Charge of Pellagra Investigations.

\section{Queries and Minor Notes}

Anonymous Communications and queries on postal cards will not be noticed. Every letter must contain the writer's name and address, but these will be omitted, on request.

\section{UTILIZABLE ALCOHOL}

To the Editor:-The amount of alcohol which can be oxidized by the adult human body in twenty-four hours, that is, serve as a food, has been determined by a physiologist and formulated into a law. Can you inform me concerning the name of the physiologist, and the amount of alcohol that can be utilized?

\section{C. Mechling, M.D., Pittsburgh.}

ANSWER.-The maximal dose of alcohol has been estimated at 15 grams per day. Such an amount can be taken without causing the alcohol tension in the blood to become so high that more than the usual amount will be excreted in the kidneys and lungs. It has long been known that 90 per cent. of the alcohol ingested is burned in the body. Atwater and Benedict within the last few years have determined that as much as 99 per cent. of the alcohol ingested undergoes combustion in the organism when the amount of alcohol ingested per day is equal in quantity to that contained in 6 ounces of whisky. It is well known that alcohol tolerance depends largely on habituation of the individual to this substance. In other words, a greater combustion of alcohol occurs in the tissues of a steady drinker than in a habitual abstainer.

We are unable to find any reference to the formation of a law for the determination of alcohol utilized in the human body.

\section{TESTS FOR ACETONE IN URINF.}

To the Editor:-Sajous quotes from ThE Journal regarding tes:8 for acetone in the urine, those of Stock and Denigès. I have no description of these tests and would appreciate the information from you. H. A. W. Brown, Cookstown, Ont.

ANSwer.-These tests were described in an article by Dr. A. E. Taylor, "Tests for Acetone in the Urine" (THE JourNAL, March 17, 1906, p. 790). The technic is as follows:

1. The Stock test: The distillate of the urine is used. From 50 to 100 c.c. of urine are made acid by the addition of either acetic, hydrochloric or sulphuric acid. The first 10 c.c. of distillate will contain all the possible acetone. About an inch of the distillate is placed in a test tube; a drop or two of a 10 per cent. solution of hydroxylamin hydrochlorid are added, and sufficient sodium hydroxid or carbonate to render the solution alkaline to liberate hydroxylamin; the mixture is shaken and a couple of drops of pyridin are added and the mixture shaken; then an inch of ether is added and the mixture shaken. Bromin water is then added drop by drop, with mixing until the ether layer becomes yellow; then a few drops of strong hydrogen peroxid are added; if acetone is present, the ether will turn a distinctive green blue.

2. The Denigès test: In the test of Denigès about an inch of the distillate in a test tube is mixed with an equal amount of a solution of the subsulphate of mercury (mercuric oxid 50 , sulphuric acid 200 , water up to 1,000 ) and the mixture allowed to simmer in a stoppered flask for about five minutes. A white crystalline precipitate occurs on cooling, which is very distinctive in appearance. If acetone is present in excess, the test is less distinct. If but a trace is present, a trace of sodium chlorid will aid the precipitation. The precipitate is not soluble in dilute hydrochloric acid.

\section{CHOLOGESTIN AND TABLOGESTIN}

To the Editor:-Are the enclosed claims of chologestin and tablogestin true? Or shall I try it myself? JAN CEpelkA, M.D., Chicago.

Answer.-The "enclosed claims" are the literature issued by F. H. Strong Company, New York, concerning chologestin and tablogestin. Chologestin is said to be a liquid of which 100 c.c. contains the amorphous sodium salt of glycocholic acid, $0.858 \mathrm{gm}$.; true sodium salicylate from the natural oil of wintergreen, $1.07 \mathrm{gm}$.; pancreatin, $2.15 \mathrm{gm}$., and sodium bicarbonate $2.15 \mathrm{gm}$., in a menstruum containing 15 per cent. alcohol. Each half ounce is said to contain the amorphous sodium salt of glycocholic acid, 2 grains; true sodium salicylate from the natural oil of wintergreen, $2 \frac{1}{2}$ grains; pancreatin, 5 grains, and sodium bicarbonate, 5 grains. According to the manufacturers, tablogestin is chologestin in tablet form, and three tablets of tablogestin are said to contain the active medicinal ingredients of 1 tablespoonful of chologestin. The statement is made:

"Tablogestin (and Chologestin), because of the combined digestive properties of the bite salt and pancreatin, materially aids in the intestinal digestion of the various foods and thus assists in the control of the fermentative and putrefactive changes that might otherwise ensue."

Bile salts do facilitate the action of the pancreatic juice in the intestines, but this applies only to bile salts of endogenous origin; that is, bile that is secreted in correlation with pancreatic secretion. It is doubtful if the pancreatin used in this mixture could ever enter into a digestion process in the intestine. As a consequence of the cholagogue action it might be admitted that it has an indirect influence on digestion in the intestine; this would, however, be offset by its disturbing influence on the digestive process in the stomach, as it is known that bile salts precipitate pepsin.

\section{ARTICLES ON LEUKEMIA}

To the Editor:-Please give me the more important references in the literature on leukemias in general, more particularly acute leukemia. C. R. BIRD, M.D., Greensburg, Ind.

ANSWER.-The following is a partial list of articles published during the past two years:

Billings, F.: Benzol in Treatment of Leukemia, The Journal, Feb. 15,1913, p. 495 .

Warthin, A. S.: Minute Changes Produced in Leukemic Tissues by Exposure to Roentgen Rays, Am. Jour. Med. Sc., January, 1914; abstr., The Journal, Jan. 31, 1914, p. 407

Smith, F. H.: Benzol Treatment in Two Cases of Leukemia, THx Journal, March 21, 1914, p. 921.

Non-Formation in Leukemia of Agglutinins for Typhoid Bacilli, Current Comment, The Journal, April 18, 1914, p. 1259.

Brown, E. J.: Acute Lymphatic Leukemia after Tetanus Serum Anaphylaxis, The Journal, May 9, 1914, p. 1473.

Pulawski, A.: Roentgen Rays and Benzol in Leukemia, Wien. klin. Wchnschr., May 7, 1914; abstr., THE JouRNAL, June 13, 1914 p. 1935.

Sappington, S. W., and Pearson, W. A.: Leukemias Under Benzol, ThE Journal, July 11, 1914, p. 143 .

Kiralyf, G.: Intramuscular Injections of Blood in Treatment of Leukemia, Wien. klin. Wchnschr. July 30, 1914; Journal, Sept. 26, 1914, p. 1143

Graham, C. F.: Case of Splenomyelogenous Leukemia Treated with Benzol, The Journal, Feb. 6, 1915, p. 505.

Simon, C. E., and Judd, C. C. W.: Acute Lymphatic Leukemia, Tra F : Benzol in Leukemia, The Journar, May 22, 1915, p. 1734 .

Beifeld, A. F.: Case of Acute Myeloid Leukemia, Arch. Diagnosis, July, 1915.

Boardman, W. W.: Benzene Treatment of Leukemia, California State Jour. Med., September, 1915. . A Case of Ireland, R. A., and Ruhräh, J.: A Case of Lymphatic Leukemia
with Apparent Cure, The Journal, Sept. 11, 1915, p. 948. Steinke, C. R.: Leukemia: Report of Two Cases, THE Journal, Sept, 11, 1915 Leukemia:

Leukemia, Therapeutics, ThE Journal, Oct. 9, 1915, p. 1280. 